\title{
Innovative Method of Urban Planning Management Based on the Mathematical Modelling of the Network Objects
}

\author{
Dmitriy Anufriev ${ }^{1}$, Olga Shikulskaya ${ }^{2 *}$, Mikhail Shikulskiy ${ }^{3}$ and Alyona Naberezhnaya ${ }^{2}$ \\ ${ }^{1}$ Astrakhan State University of Architecture and Civil Engineering, rector, 414056, 18, Tatishcheva \\ St., Astrakhan, Russian federation \\ ${ }^{2}$ Astrakhan State University of Architecture and Civil Engineering, Department of fire safety and \\ water use, 414056, 18, Tatishcheva St., Astrakhan, Russian federation \\ ${ }^{3}$ Astrakhan State Technical University, Department of applied informatics in economy, 414056, 16, \\ Tatishcheva St., Astrakhan, Russian federation
}

\begin{abstract}
When urban planning for convenience of the population and business it is necessary to place rationally objects of retail trade and service. Currently a large number of different methods are available to achievement of this purpose, but they are not universal. The most effective solutions could be achieved through the transfer of laws from one area of knowledge to another. The Coulomb's law was used. Authors analyzed all factors affecting the incurrence of profits or losses of a retail network.
\end{abstract}

\section{Introduction}

Creation of retail distribution networks is one of modern methods of management of the trade capital allowing to receive economy of expenses from change of scale of activity. In the conditions of the amplifying competition in trade there is a need of the fastest return of the monetary assets put in material assets. At this stage of development of retail trade, according to experts, the largest speed of return of monetary assets is provided by retail distribution networks. Therefore, network retail trade is not only the largest, but also the most important sector both for trade, and for economy in general.

It is well-known that in the developed countries distribution networks have captured all market space, no more than $4-6 \%$ of the market of retail trade are the share of a share of other retail points (small shops, benches). In Russia the market of network trade only gains steam. Today in our country about $20-30 \%$ of the market of retail trade are the share of network retail trade. Therefore, she has rather big prospects for the further development [7].

In this regard and development of the available networks of shopping facilities and creation of new ones is a topical issue of the modern market. But it is necessary to consider that creation of a retail distribution network requires the solution of a number of important questions among which the optimum location of new outlets and distribution centers as losses from an irrational arrangement can be enormous is prime.

\footnotetext{
Corresponding author: shikul@ mail.ru
} 
Complexity of a problem of optimum placement is, as a rule, connected with shortage of information on the market. Besides, there is a set of the various factors influencing the location choice. Usually at permission of similar problems modern businessmen rely on the experience and intuition [3] that not always leads to the right decisions.

This problem is multidimensional, and its decision covers economic, social, townplanning and other tasks. The optimality of an outlet location depends on a number of factors, since infrastructure of the region and finishing with a social and economic level of development of the population of the considered region. Therefore, there was a need of formalization of a placement problem.

\section{Methods}

For the first time the problem of placement has been presented formally at the beginning of last century by Alfred Weber [8] who has formulated a problem of placement of one warehouse as a mathematical task with minimization of the general way between a warehouse and group spatially of the distributed consumers. His work has drawn attention of scientific community and has generated the whole galaxy of various approaches and theories in the placement problem solution. The part of developments of a method of placement has been directed to adaptation of the methods borrowed from other sciences. The axiomatics which can't reflect economic regularities fully, as a rule, is the cornerstone of these methods. Therefore, these methods have very narrow scope of application in economy. Other direction in development of methods of the placement problem solution is based on use of modern mathematic-statistical methods: game theory [8, 22], geographical information systems [3], system analysis [7], mapping [5], theory of casual fields, etc. Application of these methods is complicated by need of a large number of basic statistical data that demands thorough capital investments for their collecting and processing. The special attention should be paid to the quantitative research receptions of the placement problem solution based on developments of economic-mathematical and economical and statistical methods. Quantitative methods allow to minimize subjectivity and to increase validity and efficiency of making decision on placement of an object of business.

Despite a large number of works in this direction, there is no uniform approach to classification and formalization of methods of placement of business systems. Most often classification of placement methods by object of placement meets, as the type of object is an essential factor at the solution of the put problem. Depending on quantity of the considered factors methods share on one-factor methods and multiple-factor ones. It is also possible to classify placement methods by criterion of optimization as the solution of an optimization problem directly depends on the choice of parameter by which optimization is performed. By the type of a solvable placement problem they distinguish the methods allowing to solve continuous placement problems or discrete one. Methods of the solution of a continuous placement problem have the general feature: their use means a possibility of object placement in any coordinate of the considered territory that not always corresponds to reality. If after use of a method the place in which business object placement is impossible has been defined, then additional research of nearby suitable locations is necessary [5]. The idea of the location choice from in advance established points of placement is the cornerstone of the solution methods of the placement discrete problem [2].

As a result of the analysis [3-5,7-13,16-19,22,25], the methods are classified as follows:

1. Continuous problems of placement

1.1. Method of the gravity center

1.2. Method of equilibrium system of transport expenses

1.3. Method of search of a minimum of transport work

2. Discrete problems of placement 
2.1. Method of minimum of total expenses

2.2. Factor-rating systems

2.3. Method of the weighed factor loadings

2.4. Multiple regression model

2.5. Methods of definition of influence zones on consumers

2.5.1. Method of isochronous lines

2.5.2. Method of Tyapukhin

2.5.3. Method on the basis of the fuzzy sets theory

The considered methods don't limit a wide range of placement models. Other approaches and schemes are possible. The given methods testify to a possibility of the mathematical description and optimization of a problem of placement of object of business. But not one of the specified methods isn't universal, meeting all requirements and inquiries of the modern market. Depending on specifics of a task, from quantity of factors which will influence the location choice the corresponding method of placement will be used. Use of several methods, comparison and the analysis of the received results on each method will be the best.

Also it should be noted that the methods existing today and models of placement of objects have a number of shortcomings and they are intended for optimization of placement of separate objects of business, but aren't applicable for optimization of placement of a network of objects, i.e. they don't consider interrelation between the placed objects, their communication with a distribution center, etc. [15].

Thus, the business object placement problem is completely not resolved. Any of the considered methods demands specifications and completions. Development of the integrated approaches, new methods and models including the interconnected calculations for several methods is also necessary.

\section{Development of the model of placement of a distributing facilities objects}

The most effective solutions of problems are reaching by means of transfer of the laws from one field of knowledge to another one: "... philosophers and scientists of all times are deeply convinced that there is an internal harmony of the world, and this generality can be disclosed by means of the mathematics describing visibility and perfection of the nature laws" [26. P. 486]. One of such universal laws is the inverse square law which describes interaction of gravitational fields (the law of Newton), interaction of charged particles (Coulomb's law), Biot-Savart-Laplace's law which is magnetic analog of Coulomb's law. The theory of an information field [26] has made the significant contribution to extension of the inverse square law to various fields of knowledge. Existence of the inverse square law for physics, chemistry, cosmology and a galaxy, mathematics, medicine is shown in more than in 200 works of domestic and foreign scientists.

Authors have considered the possibility of the inverse square law application for the studied subject domain. And Coulomb's law (1) was the most suitable since it considers the direction of forces of interaction depending on signs of electric charges of the interacting particles.

Using terminology of the static electricity theory we will consider demand of consumers (potential clients) for goods as negative electric charge, and the offer of goods as positive electric charge. Carriers of negative charges are consumers of production (population), carriers of positive charges are suppliers of products (the placed objects of a distribution network and the competing shopping facilities). As consumers with their various inquiries are distributed across the studied territory unevenly, in total they can be considered as nonuniform negatively charged electric field. For simplification of a task we will replace 
continuous function of distribution of negative electric charge (consumer demand) on the Cartesian plane on a district map with discrete one. We will partition the territory by coordinate lines into rectangularity areas. For simplification we will consider the that "field of a consumer demand" of such area similar to negatively charged electric field, is uniform. We will consider the "center" of such rectangularity area inhabited by consumers, which is on crossing of diagonals, a dot negative charge. We will consider the negative charges of "consumer demand" and positive charges of "offer" created by the competing centers of trade motionless, and a placed object of a distributing facilities is a moved positively charged particle (fig. 1).

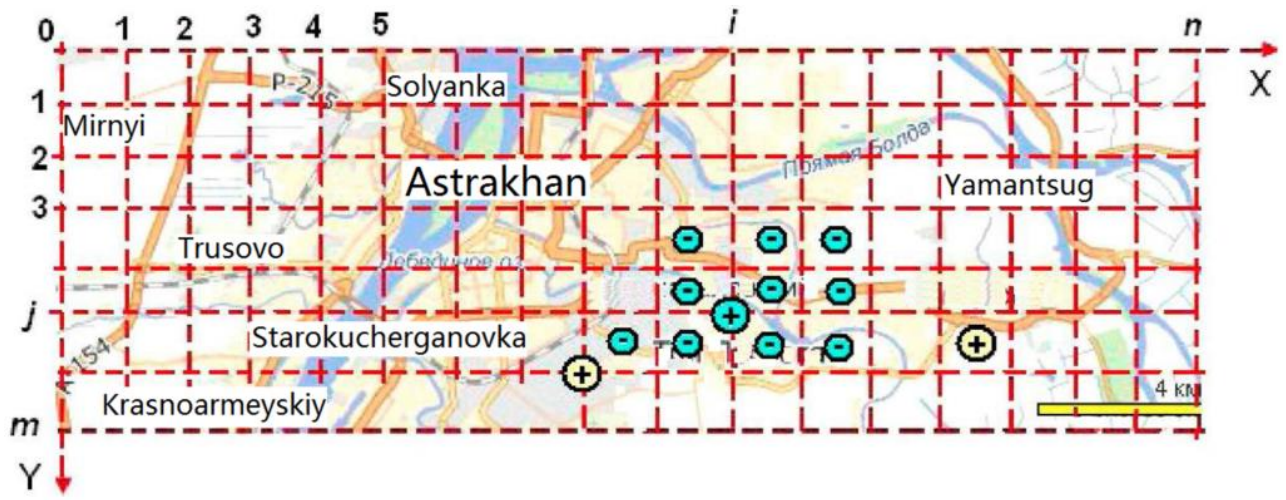

Fig. 1. The scheme of placement of objects of a consumer demand and the offer on Cartesian plane of a district map.

As a result, we have the law similar to Coulomb's law: all shopping facilities will "push away" from each other, but the placed shopping facilities will "be attracted" to considered "points" with potential clients:

$$
F=\frac{q_{1} \cdot q_{2}}{k r^{2}}
$$

The description of designations in a formula (1) is presented in the table 1 of quantitiesanalogs.

Table 1. Matching of values and analogues.

\begin{tabular}{|c|c|c|}
\hline \multirow[b]{2}{*}{ Sign } & \multicolumn{2}{|r|}{ Quantity } \\
\hline & Coulomb's law & $\begin{array}{c}\text { Interaction of objects of a distributing } \\
\text { facilities }\end{array}$ \\
\hline$F$ & Force of interaction of charges & $\begin{array}{l}\text { Quantity of mutual influence of objects } \\
\text { and subjects of trade }\end{array}$ \\
\hline$q_{1, q_{2}}$ & $\begin{array}{l}\text { Values of the interacting } \\
\text { charges }\end{array}$ & $\begin{array}{l}\text { Quantity characterizing demand for } \\
\text { goods and its satisfaction }\end{array}$ \\
\hline$k$ & $\begin{array}{l}\mathrm{k}=4718, \text { where } \varepsilon \text { is dielectric } \\
\text { permeability }\end{array}$ & $\begin{array}{l}\text { Coefficient of permeability of the } \\
\text { environment of interaction }\end{array}$ \\
\hline$r$ & Distance between charges & $\begin{array}{l}\text { Distance between objects and subjects of } \\
\text { trade }\end{array}$ \\
\hline
\end{tabular}

The value of charges will depend on various factors. Authors have analyzed all factors influencing the size of the distribution network got profits / losses from functioning of 
objects. Criteria and their indicators have been connected with the estimated objects (the placed shopping facility and the competitor, potential client base and permeability of the environment). Criteria of the placed shopping facility and the competitor are price level, quality of service, amount of capital investments, size of a floor space, format of shop, commodity turnover volume. Criteria of potential client base are object maintenance costs, existence of a warehouse, system of discounts, population density, income level, structure of the population, age, existence of the vehicle, frequency of shopping, consumer streams. Criteria of the environment permeability are transport streams, communications and services, public institutions, parking. Quality and quantitative indicators have been defined for each criterion.

After calculation of the interacting forces for a formula (1) we will apply the third law of Newton (2):

$$
\sum \vec{F}_{i}=0
$$

The steady condition of the placed object will be defined by balance of all forces operating on it (fig. 2).

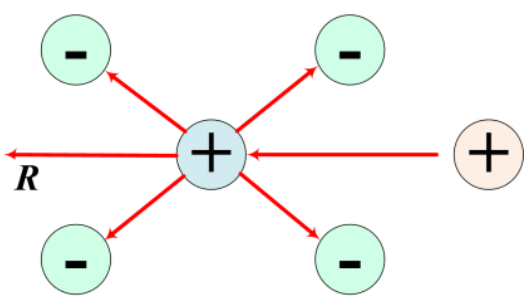

Fig. 2. Scheme of interaction between objects of trade and consumers.

We will consistently move the placed object on areas of the Cartesian plane and to each area and will count value of estimated function on the got profit depending on criteria.

The offered method allows to consider a variety of the factors influencing placement of object. The software developed on the basis of such model will allow to define location of outlets of a network rather precisely.

\section{Results and discussion}

Authors have analyzed all of the factors affecting the incurrence of profits (or losses) from the perspective of a retail network.

A large number of the input parameters including the mutually influencing factors an ambiguity of influence extent of each of parameters interferes with effective modeling. In this regard, there is a need of the preliminary analysis of the influencing factors for the purpose of an exception of slightly influencing and interconnected criteria.

One of the most effective approaches for the solution of this task is the methodology of cognitive modeling offered by Axelrod [1]. It has gained development in many works $[11,13,15,20]$.

The questionnaire has been developed for creation of a cognitive map and questioning of the population and the experts competent of questions of trade business is carried out [12]. The analysis of questioning results has allowed to specify the fundamental factors influencing demand of consumers, the direction and extent of their influence on demand. Processing of questionnaires has allowed to confirm that level of demand on the servant of 
the shopping facility, is inversely proportional to a quadrate of distance which the consumer is ready to overcome to make purchases.

At the following stage of map development experts established relationships of cause and effect between factors with the indication for each connection of its character (strengthening it or weakening).

At last, at the third stage experts were offered to estimate force of each influence. Verbal judgments of experts have been formalized by means of the scale developed by authors.

By results of this stage the cognitive matrix of interferences containing average estimates of intensity of influences (according to each expert) has been created [12].

The developed cognitive map has allowed authors to draw conclusions on relevance of factors of shopping facilities placement, to select a number of the indicators exerting considerable impact on supply and demand in trade business that in turn defines optimum places of dislocation of shopping facilities. As a result of the conducted research, it was succeeded to reveal and exclude a number of insignificant difficult formalizable factors, such as a format of shop, quality of service and frequency of shopping.

Also the analysis of the developed cognitive model has shown that among the considered criteria there are several indicators-consequences on which the vast majority of factors-reasons exerts impact. For elimination of an ambiguity and duality at further creation of mathematical model of optimization of the retail network objects placement arising because of use of the mutually influencing factors, authors have excluded from the list of criteria of optimization of placement such factors as level of demand, price level and profit level. In general, from 22 considered factors, 6 criteria have been excluded.

Cognitive modeling has allowed to confirm that level of demand on the servant of the shopping facility, is inversely proportional to quadrate of distance which the consumer is ready to overcome to make purchases.

Thus, creation of a cognitive map has helped authors with development of full-fledged hierarchical system of criteria of optimization of placement of objects of trade.

\section{Conclusions}

The authors show the modern market is facing an acute problem related to the development of existing retail chains and the establishment of new ones. However, a number of important issues - such as the emplacement of new stores to replace inefficient older ones need to be resolved as a pre-condition to creating new retail networks.

Networking facilities for trade is the long-term trend of modern retail business. Unreasonable placement of outlets could lead to big financial losses. As a rule, the complexity of the problem of optimal placement associated with lack of market information and a variety of different factors influencing the choice of location.

The authors have presented the review and classification of the best known methods of optimal placement of business objects. We consider such methods of solving optimization problems as mathematical and statistical, quantitative methods and methods borrowed from other sciences. Particular attention is paid to quantitative research methods of solving of the placement problem, which are based on mathematical economic development and economic and statistical methods and minimize subjectivity and increase the validity and effectiveness of the decision on placing the object of business. We give a brief description and link to each other, identify the main strengths and weaknesses, and define the boundaries of applicability of the factors involved in each method. There is no single approach to classification and formalization of placement methods of business systems. It is concluded that none of these methods is not universal and does not meet all requirements 
and demands of the market. We identify the need to develop integrated approaches, new methods and models which include interrelated calculations by several methods.

The paper indicates that currently there are a large number of different methods available for selecting the placement of retail networks, but none of these is universal nor addresses all of the market-related demands.

The most effective solutions, in the critique's view, could be achieved through the transfer of laws from one area of knowledge to another. One of these universal laws is the inverse square law (Newton's law), which describes the interaction of gravitational fields, while another (Coulomb's law) covers the interaction of charged particles and the BiotSavart-Laplace magnetic analog.

The study has considered the possibility of using either Newton's or Coulomb's law to resolve the challenge at hand. The latter, which it suggests is most suitable, would take into account the direction of the forces of interaction, depending on the activity caused by interacting participants. In conclusion the research authors have analyzed all of the factors affecting the incurrence of profits (or losses) from the perspective of a retail network.

Authors have executed cognitive modeling which has allowed to confirm that level of demand on the servant of the shopping facility, is inversely proportional to a quadrate of distance which the consumer is ready to overcome to make purchases.

Thus, creation of a cognitive map has helped authors with development of full-fledged hierarchical system of criteria of optimization of placement of objects of trade.

Further on the basis of the developed models authors plan to create system of support of decision-making on placement of objects of a network of retail trade.

\section{References}

1. Axelrod R. The Structure of Decision: Cognitive Maps of Political Elites. - Princeton, NJ: Princeton University Press, 1976.

2. Bochkova A. B. Roznichnye torgovye seti: sostoyanie i perspektivy razvitiya [Retail trade net-works: state and development prospects]. Saratov, Scientific Book, 2008. 205 p.

3. Chase R., Ekvilayn N. J., Jacobs R. F. Proizvodstvennyj i operacionnyj menedzhment: per. s angl. M., Williams, 2001. - 704 p.

4. E. Elhedhli, "Service System Design with Immobile Servers, Stochastic Demand, and Congestion," Manufacturing and Service Operations Management, Vol. 8, No. 1, 2006, pp. 92-97.

5. Endzhel Dzh. F., Ble'kue'll R. D., Miniard P. U. Povedenie potrebitelej,- SPb. : Piter Kom, 2000. - 759 p.

6. Esjutin A.A. E.V. Karpova E.V. Roznichnyetorgovyeseti: strategii, jekonomikaiupravlenie: uchebnoeposobie. - M.:Knorus, 2007

7. Gadzhinskij A. M. Osnovy logistiki, M. : IVCMK, 1996. - 124 p.

8. Granberg A. G. Osnovy regionalnoj ekonomiki, M., GU VSHE, 2000. - 495 p.

9. H. Tijms, "A First Course in Stochastic Models," Wiley, New York, 2003.

10. I. Castillo, A. Ingolfsson and T. Sim, "Social Optimal Location of Facilities with Fixed Servers, Stochastic Demand, and Congestion," Production and Operations Management, Vol. 18, No. 6, 2010, pp. 721-736.

11. Kosko B. Fuzzy cognitive maps // International Journal of Man-Machine Studies, 1986 (24). 
12. Naberezhnaja A.V., Shikul'skaja O.M. Postroenie nechetkoy kognitivnoy karti protsesa optimizatsii razmescheniya torgovogo ob'ekta, Innovatsii na osnove informatsionnokommunikatsionnih nekhnologiy. 2013. T. 1. C. 547-549.

13. Naberezhnaja A.V., Shikul'skaja O.M. Razrabotka modeli optimal'nogo razmeshhenija obyektov seti roznichnoj torgovli na osnove zakona obratnogo kvadrata // Prikaspijskij zhurnal: Upravlenie i vysokie tehnologii [Caspian Journal: Management and High Technologies], 2012, 4 (20), System analisys, mahematical modeling, pp.54-59

14. Naberezhnaya A. V., Shikulskaya O. M. Obzor kolichestvennykh metodov optimizatsii razmesh- cheniya obektov biznesa [Review of quantitative methods of business object location optimization], Pri- kaspiyskiy zhurnal: upravlenie i vysokie tekhnologii [Caspian Journal: Management and High Technologies]. Astrakhan, Astrakhan State University, Publishing House "Astrakhan University", 2012, no. 1 (17), pp. 142- 146.

15. O. Baron, O. Berman and D. Krass, "Facility Location with Stochastic Demand and Constraints on Waiting Time," Manufacturing and Service Operations Management, Vol. 10, No. 3, 2008, pp. 484-505.

16. O. Berman, D. Krass and J. Wang, "Locating Service Facilities to Reduce Lost Demand," IIE Transactions, Vol. 38, No. 11, 2006, pp. 33-946.

17. Q. Wang, R. Batta and C. Rump, "Algorithms for a Facility Location Problem with Stochastic Customer Demand and Immobile Servers," Annals of Operations Research, Vol. 111, No. 1-4, 2002, pp. 17-34.

18. R. Boffey, R. Galvao and L. Espejo, "A Review of Congestion Models in the Location of Facilities with Immobile Servers," European Journal of Operational Research, Vol. 178, No. 3, 2007, pp. 643-662.

19. Roberts F.S. Diskretnyematematicheskiemodeli s prilozhenijami k social'nym, biologicheskimij ekologicheskim zadacham. - M.: Nauka. Gl. red.fiz.-mat. lit., 1986.

20. Silov V.B. Prinjatie strategicheskih reshenij v nechetkoj obstanovke. - M.: INPRORES, 1995.

21. Smekhov A. A. Marketingovye modeli transportnogo rynka, M, Transport, 1998. - 120 p.

22. T. Hamaguchi and K. Nakade, "Optimal Location of Facilities on a Network in Which Each Facility is Operating as an M/G/1 Queue," Journal of Service Science and Management, Vol. 3 No. 3, 2010, pp. 287-297. doi:10.4236/jssm.2010.33036

23. TrahtengercJe.A. Komp'juternaja podderzhka prinjatija reshenij. - M.: SINTEG, 1998.

24. Tyapuhin A. Novaya strategiya sbyta: Proektirovanie i formirovanie logisticheskih kanalov, RISK. - 1999. - № 4. - pp. 24-29.

25. Volkova V. N., Denisov A. A. Osnovy teorii sistem i sistemnogo analiza [Fundamentals of system theory and system analysis]. 2nd ed. Saint-Petersburg, Saint-Petersburg State Technical Univ. Publ. House, 2001. 512 p. 